\title{
THE EFFECT OF VARIATIONS IN SOLUTE EXCRETION AND GLOMERULAR FILTRATION ON WATER DIURESIS ${ }^{1}$
}

\author{
By CHARLES R. KLEEMAN, FRANKLIN H. EPSTEIN, AND COLIN WHITE
}

(From the Department of Internal Medicine and the Biometry Section, School of Public Health, Yale University School of Medicine, New Haven, Conn.)

(Submitted for publication December 16, 1955; accepted March 15, 1956)

A sustained positive load of water administered to a normal subject results in maximal water diuresis associated with a minimal concentration of solutes in the urine. The term "physiological diabetes insipidus" has been applied to this situation, because under these circumstances, the release of antidiuretic hormone from the posterior pituitary is inhibited and as a consequence, that part of the water of glomerular filtrate that is normally reabsorbed under the influence of this hormone is excreted. During sustained water diuresis, therefore, variations in urinary flow, urinary osmolarity, and "free water clearance" $\left(\mathrm{C}_{\mathrm{H}_{2} \mathrm{O}}\right)$ (1) might be ascribed to factors other than antidiuretic hormone.

In the present study, the effect of variations within the physiological range of solute load, dietary composition and endogenous creatinine clearance upon these parameters were investigated in normal subjects in a state of "physiological diabetes insipidus," in whom the level of circulating antidiuretic hormone was presumably at a minimum. The results indicate that both glomerular filtration rate (endogenous creatinine clearance) and solute load have important and statistically separable effects on the characteristics of water diuresis.

\section{MATERIALS AND METHODS}

Twenty-nine experiments were performed on fourteen healthy young male medical students and physicians. After a light breakfast at 7:00 A.M. the experiment was begun at about 8:30 A.M. and varied in length from $3-1 / 2$ to $5-1 / 2$ hours. The subjects remained in the semirecumbent position throughout, getting up only to void.

In twelve paired experiments on six subjects a "highsolute diet" or a "low-solute diet" was ingested for three days prior to the experiment. The "high-solute diet" contained approximately 150 grams of proteins and 10 to 15 grams of salt; the "low-solute diet" contained less than 25 grams of protein and 5 grams of salt. In all other experiments diet was uncontrolled. Subjects drank

\footnotetext{
${ }^{1}$ Supported by United States Public Health Service Grants A-625 and H-834.
}

one liter of water upon reclining. A sustained positive balance of one liter was maintained throughout the rest of the experiment by oral ingestion of water and by the infusion of 2.5 per cent fructose in water at rates below that necessary to produce glycosuria when tested with Benedict's solution.

Sodium, potassium and chloride in serum and urine were measured by methods previously described $(2,3)$. Creatinine in serum and urine was determined by a modification of the method of Hare (4). Endogenous creatinine clearance was used to approximate glomerular filtration rate. Urea in serum and urine was measured by a micro-diffusion technique (5) ; and the osmolarity of serum and urine was measured by freezing point depression using a Fiske osmometer. These results are obtained in milliosmols per kilogram of water. Free water clearance $\left(\mathrm{C}_{\mathrm{H}_{2} \mathrm{O}}\right)$ was calculated as the difference between urinary flow $\mathrm{V}$ and osmolar clearance: $\mathrm{C}_{\mathrm{H}_{2} \mathrm{O}}=$ $\mathrm{V}-\frac{\text { UosmV }}{\text { Posm }}$ (1), where $\mathrm{V}=$ urinary flow (cc. per $\min$ ); Posm $=$ osmolar concentration of plasma (mOsm. per $\mathrm{Kg}$.) ; Uosm $=$ osmolar concentration of urine (mOsm. per Kg.).

\section{RESULTS}

\section{Effect of variations in solute excretion upon water diuresis}

a. Maximal urinary flow (Table I) : Maximal urinary flow varied from 9.7 to $23.7 \mathrm{cc}$. per minute per $1.73 \mathrm{~m}^{2}$, and was directly related to the concomitant rate of excretion of solute (Figure 1 and Table IIa). Using the statistical technique of multiple regression analysis (see below), it was apparent that variations in the rate of excretion of either electrolytes $([\mathrm{Na}+\mathrm{K}] 2)$ or non electrolytes (total urinary osmols $-[\mathrm{Na}+\mathrm{K}] 2$ ) had no significant separate effect over and above their contribution to the total solute excretion (Table III).

b. Minimal urinary osmolarity (Table I): At the height of water diuresis urinary osmolarity varied from 40 to 85 milliosmols per $\mathrm{Kg}$. with a mean of 62.5 milliosmols per $\mathrm{Kg}$. This minimal urinary concentration was higher in the same sub- 
TABLE I

Tabulation of variables *

\begin{tabular}{|c|c|c|c|c|c|c|c|c|c|}
\hline Subject & $\begin{array}{c}\text { Surface } \\
\text { area } \\
M^{2}\end{array}$ & $\begin{array}{l}\text { G.F.R. } \\
c c . / \text { min. }\end{array}$ & $\begin{array}{c}\text { Solute } \\
\text { load } \\
\mu O s . / \min .\end{array}$ & $\begin{array}{l}\text { Urine } \\
\text { flow } \\
c c . / \min \text {. }\end{array}$ & ${ }_{\mu E q . / m i n .}^{[\mathrm{Na}+\mathrm{K}]_{2}}$ & $\begin{array}{c}\text { Urea } \\
\mu M / \min .\end{array}$ & $\begin{array}{c}\text { Minimal } \\
\text { urinary } \\
\text { osmolarity } \\
m O s . / K g .\end{array}$ & $\begin{array}{c}\text { Minimal } \\
\text { serum } \\
\text { osmolarity } \\
m O s . / K g .\end{array}$ & $\begin{array}{c}\mathrm{C}_{\mathrm{H}_{2} \mathrm{O}} \\
c c . / \min .\end{array}$ \\
\hline R. S. & 1.85 & & 1,517 & 23.4 & & & 69 & 285 & \\
\hline R. S. & 1.85 & & 1,200 & 15.9 & & & 68 & & \\
\hline K. S. & 2.00 & 104 & 638 & 10.0 & & & 65 & 282 & 7.8 \\
\hline M. R. & 1.90 & 121 & 715 & 11.2 & & & 59 & 279 & 8.8 \\
\hline F. E. & 1.79 & 134 & 1,014 & 17.0 & & & 62 & 283 & 13.4 \\
\hline E. S. & 2.00 & 128 & 1,207 & 20.2 & 803 & & 63 & 284 & 16.0 \\
\hline E. S. & 2.00 & 117 & 753 & 15.7 & 364 & & 49 & 275 & 13.0 \\
\hline W. H. & 2.07 & 138 & 1,100 & 20.4 & 687 & & 68 & 280 & 15.1 \\
\hline D. B. & 2.13 & 102 & 933 & 13.0 & & & 66 & 277 & 9.3 \\
\hline N. U. & 1.92 & 144 & 839 & 18.0 & 483 & & 50 & 274 & 14.8 \\
\hline M. R. & 1.90 & 121 & 828 & 11.3 & 437 & & 67 & 282 & 8.2 \\
\hline P. H. & 1.84 & 126 & 840 & 11.6 & 354 & & 77 & 284 & 8.5 \\
\hline M. R. & 1.90 & 102 & 1,235 & 12.6 & 630 & & 68 & 302 & 8.6 \\
\hline C. K. & 1.88 & 129 & 513 & 9.7 & 311 & 192 & 62 & 280 & 6.9 \\
\hline C. $\mathrm{K}$. & 1.88 & 129 & 658 & 10.6 & 258 & 402 & 71 & 276 & 7.6 \\
\hline F. K. & 2.07 & 99 & 690 & 11.5 & 363 & 242 & 57 & 287 & 8.9 \\
\hline M. S. & 1.98 & 135 & 1,185 & 16.8 & 248 & 785 & 66 & 282 & 12.7 \\
\hline C. $\bar{K}$. & 1.88 & 112 & 626 & 11.0 & 490 & 194 & 63 & 278 & 8.5 \\
\hline C. K. & 1.88 & 106 & 906 & 12.2 & 488 & 270 & 68 & 300 & 9.2 \\
\hline F. E. & 1.79 & 144 & 1,177 & 21.2 & 390 & 734 & 58 & 285 & 15.5 \\
\hline F.E. & 1.79 & 130 & 786 & 16.4 & 609 & 200 & 52 & 282 & 13.4 \\
\hline E. L. & 2.05 & 170 & 984 & 14.9 & 287 & 514 & 54 & 274 & 14.3 \\
\hline E. L. & 2.05 & 135 & 620 & 14.0 & 285 & 236 & 41 & 276 & 12.2 \\
\hline M. S. & 1.98 & 124 & 489 & 13.0 & 194 & 221 & 40 & 270 & 11.2 \\
\hline D. K. & 1.90 & 118 & 598 & 13.5 & 231 & 264 & 46 & 270 & 11.3 \\
\hline D. $\mathrm{K}$. & 1.90 & 130 & 2,000 & 23.7 & 1,965 & 290 & 85 & 270 & 16.1 \\
\hline M. S. & 1.98 & 118 & 1,310 & 17.0 & 784 & & 77 & 285 & 13.0 \\
\hline R. S. & 1.85 & 122 & 1,620 & 20.1 & & & 80 & 280 & 14.4 \\
\hline F. E. & 1.79 & 130 & 1,190 & 20.8 & 484 & 700 & 57 & 280 & 16.9 \\
\hline
\end{tabular}

* All values corrected to $1.73 \mathrm{M}^{2}$ and they represent the mean of three to five periods at the height of the water diuresis.

TABLE II

Analyses of variances of the parameters of water diuresis

\begin{tabular}{|c|c|c|c|c|}
\hline Source of variation* & $\begin{array}{l}\text { Degrees of } \\
\text { freedom }\end{array}$ & $\begin{array}{l}\text { Sum of } \\
\text { squares }\end{array}$ & $\begin{array}{c}\text { Mean } \\
\text { square }\end{array}$ & $\begin{array}{c}\text { Variance } \\
\text { ratio }\end{array}$ \\
\hline \multicolumn{5}{|c|}{ (a) Urinary flow } \\
\hline $\begin{array}{l}\text { 1) Multiple regression on } X_{1} \text { and } X_{2} \\
\text { Simple regression on } X_{2} \\
\text { Extra effect due to } X_{1} \\
\text { 2) Deviations from multiple regression } \\
\text { 3) Total }\end{array}$ & $\begin{array}{r}2 \\
1 \\
1 \\
24 \\
26\end{array}$ & $\begin{array}{r}301.05 \\
254.58 \\
46.47 \\
116.66 \\
417.71\end{array}$ & $\begin{array}{r}254.58 \\
46.47 \\
4.86\end{array}$ & $\begin{array}{r}52.40 \dagger \\
9.56 \ddagger\end{array}$ \\
\hline
\end{tabular}

(b) Minimal urinary osmolarity

1) Multiple regression on $X_{1}$ and $X_{2}$ Simple regression on $X_{2}$ $\S$ Extra effect due to $X_{1}$

2) Deviations from multiple regression

3) Total

$\begin{array}{rr}2 & 1,705.70 \\ 1 & 1,405.40 \\ 1 & 300.30 \\ 24 & 1,586.97 \\ 26 & 3,292.67\end{array}$

$$
\begin{array}{r}
1,405.40 \\
300.30 \\
66.12
\end{array}
$$

(c) Free water clearance $\left(\mathrm{C}_{\mathrm{H}_{2} \mathrm{O}}\right)$

1) Multiple regression on $X_{1}$ and $X_{2}$ Simple regression on $\mathrm{X}_{1}$

Extra effect of $\mathrm{X}_{2}$

2) Deviations from multiple regression

3) Total

131.22
80.11
51.11
82.79
214.01

80.11

51.11

3.76
$21.26 \dagger$
$4.54 \S$

* $\mathrm{X}_{1}=$ glomerular filtration rate. $\mathrm{X}_{2}=$ solute load.

† Significant $(\mathrm{P}<0.001)$.

Significant $(0.001<\mathrm{P}<0.01)$

$\$$ Significant $(\mathrm{P}<0.05)$, as indicated in the text the regression in this case is negative. 
TABLE III

Analysis of variance of urinary flow *

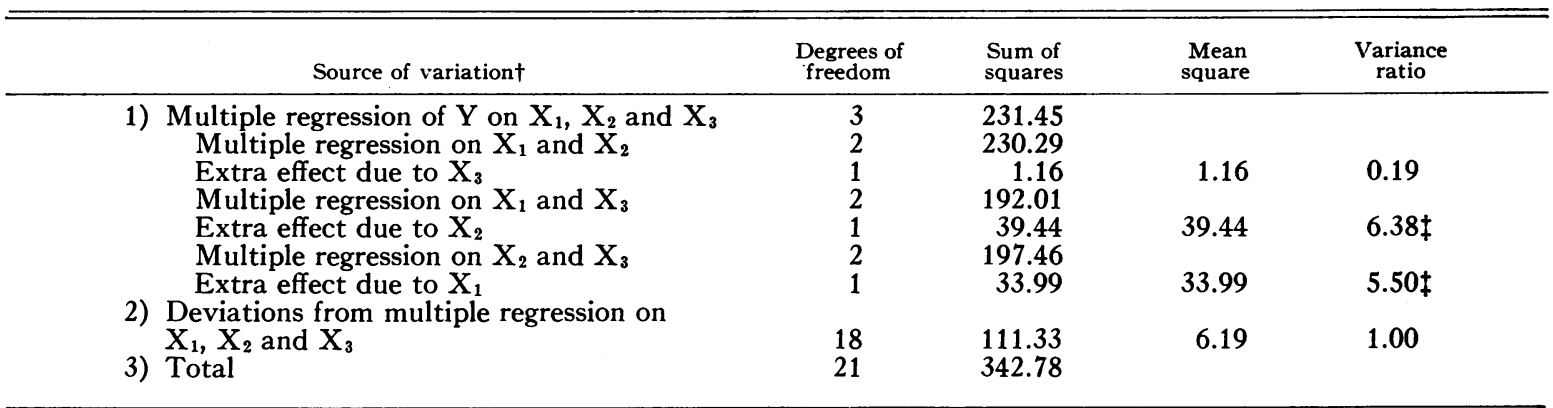

* This analysis has been placed in a separate table because of the addition of the added dependent variable of electrolyte excretion $2\left(\mathrm{Na}^{+}+\mathrm{K}^{+}\right)$and the utilization of 22 rather than 27 experiments.

$\dagger \mathrm{Y}$-urinary flow. $X_{1}=$ glomerular filtration rate. $X_{2}=$ solute load. $X_{3}=$ electrolytes.

$\ddagger$ Significant $(0.01<\mathrm{P}<0.05)$.

ject on a high-protein, high-salt diet than on a low-solute diet (Figure 2a) and its magnitude was directly correlated with the rate of solute excretion in the entire group of experiments (Figure $2 \mathrm{~b}$, Table IIb). There was no correlation between the osmolar concentration of serum and the minimal urinary osmolarity (Figure 3 ). c. Free water clearance $\left(\mathrm{C}_{\mathrm{H}_{2} \mathrm{O}}\right)$ (Table I): $\mathrm{C}_{\mathrm{H}_{2} \mathrm{O}}$ varied from 6.8 to $16.9 \mathrm{cc}$. per minute. The increase in urinary flow accompanying an increase in dietary intake and urinary output of solutes consisted not only of an increase in osmolar clearance $\left(\right.$ Cosm) but also of a rise in $\mathrm{C}_{\mathrm{H}_{2} \mathrm{O}}$. This correlation is most obvious in paired studies on the

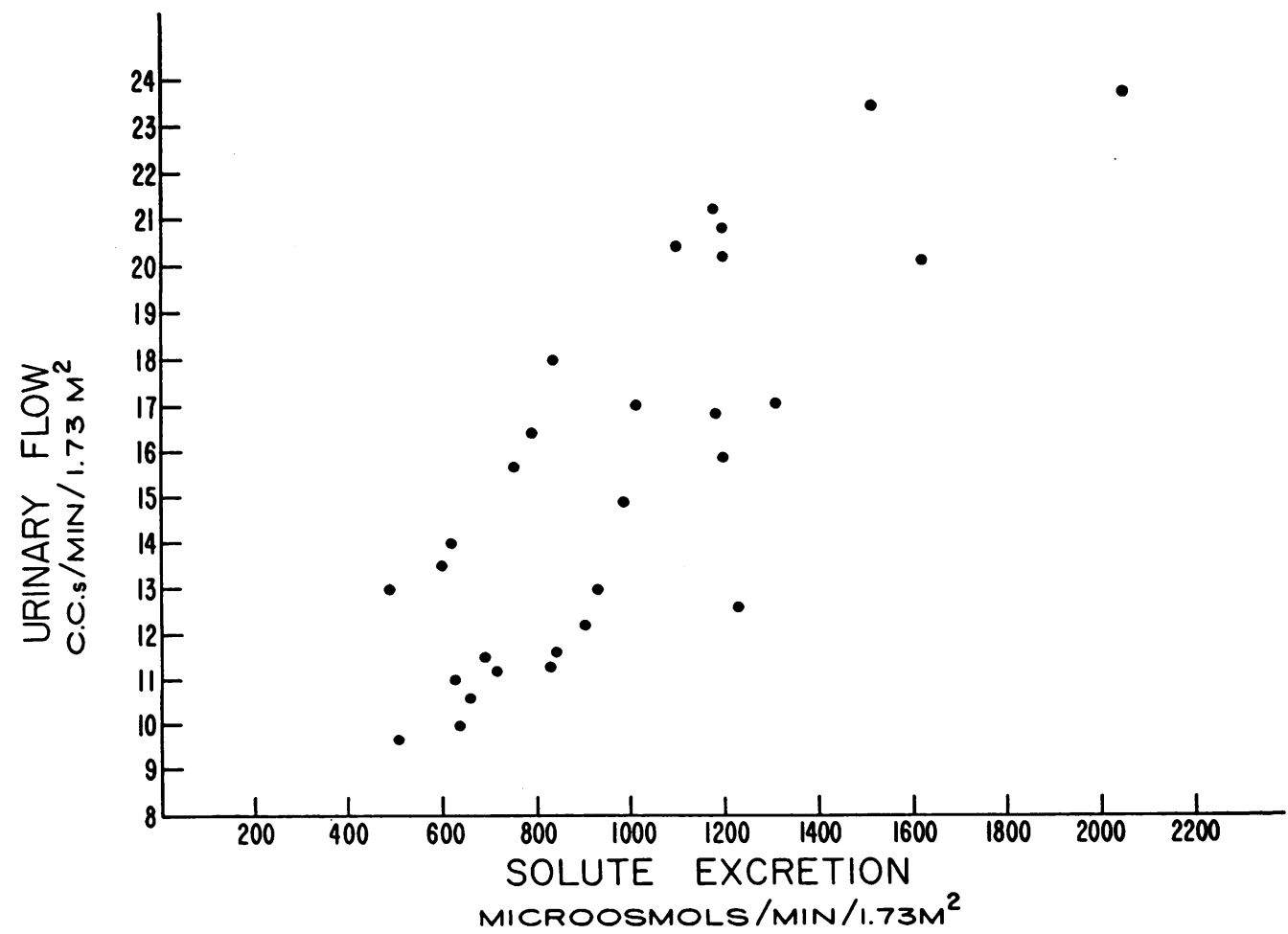

Fig. 1. The Relationship Between the Maximal Urinary Flow and the Rate of Solute Excretion at the Height of Sustained Water Diuresis 


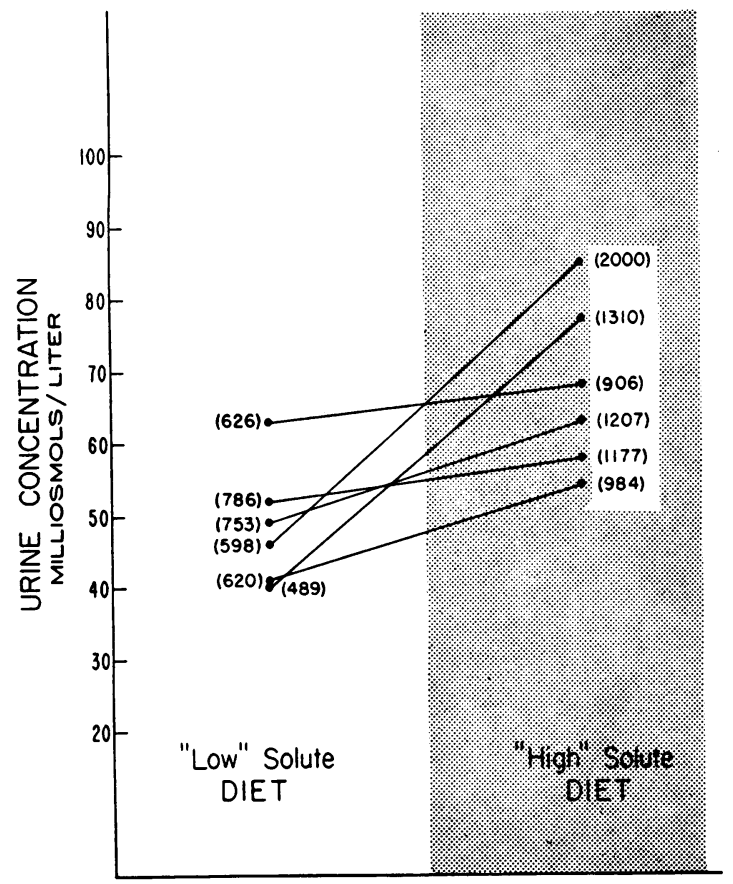

Fig. 2a. Illustration of the Effect of an INCREaSe in the Rate of Solute Excretion upon the Minimal Urinary Osmolarity in Paired Dietary EXPERIMENTS

The numbers in parentheses represent the rate of solute excretion in microosmols per minute.

same subject (Figure 4a) but is also apparent when all the data are plotted as in Figure $4 \mathrm{~b}$ and treated statistically (Table IIc).

\section{Effect of variations in glomerular filtration rate (endogenous creatinine clearance) upon water diuresis}

Because it is difficult, in single experiments in human subjects, to produce variations in glomerular filtration rate without simultaneously altering the rate and pattern of solute excretion, the statistical method of multiple linear regression analysis (6) was resorted to in order to attempt to evaluate the effect of changes in endogenous creatinine clearance per se upon the parameters of water diuresis. The following is a brief description of the statistical method.

The effects of creatinine clearance and solute load were tested, using in turn, urinary flow, minimal urinary osmolarity and $\mathrm{C}_{\mathrm{H}_{2} \mathrm{O}}$ as the dependent variable. In principle the method is to subdivide the total variation found in the dependent variable into various meaningful components: (a) that due to the independent variables, namely solute load and creatinine clearance, and (b) a remainder, which is loosely classified as error, and is due to factors not included in the analysis as well as to imperfect reproducibility of the measurements.

The results from each experiment may be represented by a point in three-dimensional space with co-ordinates $x_{1}, x_{2}$ and $y$, where $x_{1}$ is the creatinine clearance rate, $x_{2}$ the solute load and $y$ the urine flow. A plane may then be fitted by the method of least squares to the swarm of points. If this plane is effectively parallel to the plane containing $x_{1}, x_{2}$ then the independent variables are without detectable influence on the dependent variable. If the fitted plane is sloped in such a way that $y$ changes significantly with either $x_{1}$, or $x_{2}$ or both then the appropriate independent variable is said to have an effect on $y$. The decision as to what change is regarded as significant must be made in the light of the "error" of the model used, that is the deviations between the values of y predicted from the fitted plane and the values actually observed. The tests of significance are formally carried out by means of the analysis of variance. The results are shown in Tables II and III.

a, Maximal urinary flow (Table IIa) : A preliminary examination by the method of simple linear regression showed that each of the factors, creatinine clearance and solute load, considered separately, was significantly related to the magnitude of urine flow. ${ }^{2}$ The sum of squares accounted for by the regression on solute load alone was 254.58 and that accounted for by regression on creatinine clearance alone was smaller, namely 85.66. However, these two factors are themselves correlated and it was therefore necessary to decide whether creatinine clearance produced an effect over and above that attributed to solute load, or whether the effect apparently due to creatinine clearance arose simply from correlation of this

2 It should be pointed out that in making this analysis we have assumed that the 29 sets of observations are independent, whereas, in fact, the data were collected from only 14 subjects. When a subject was examined on a second occasion, however, the conditions as regards diet were quite different from the first and it is possible that the changes thereby produced were so great as to make differences between subjects unimportant. This assumption has been tested by running an analysis on data in which each subject is represented only once. The results obtained completely confirm those reported below with the single exception that the effect of glomerular filtration rate on minimal urinary osmolarity, though qualitatively identical with that reported, does not rise to the level of statistical significance. In view of this general confirmation it is considered reasonable to treat the observations on the same subject as if they were independent, though anyone who preferred not to do this would arrive at essentially the same conclusions. 


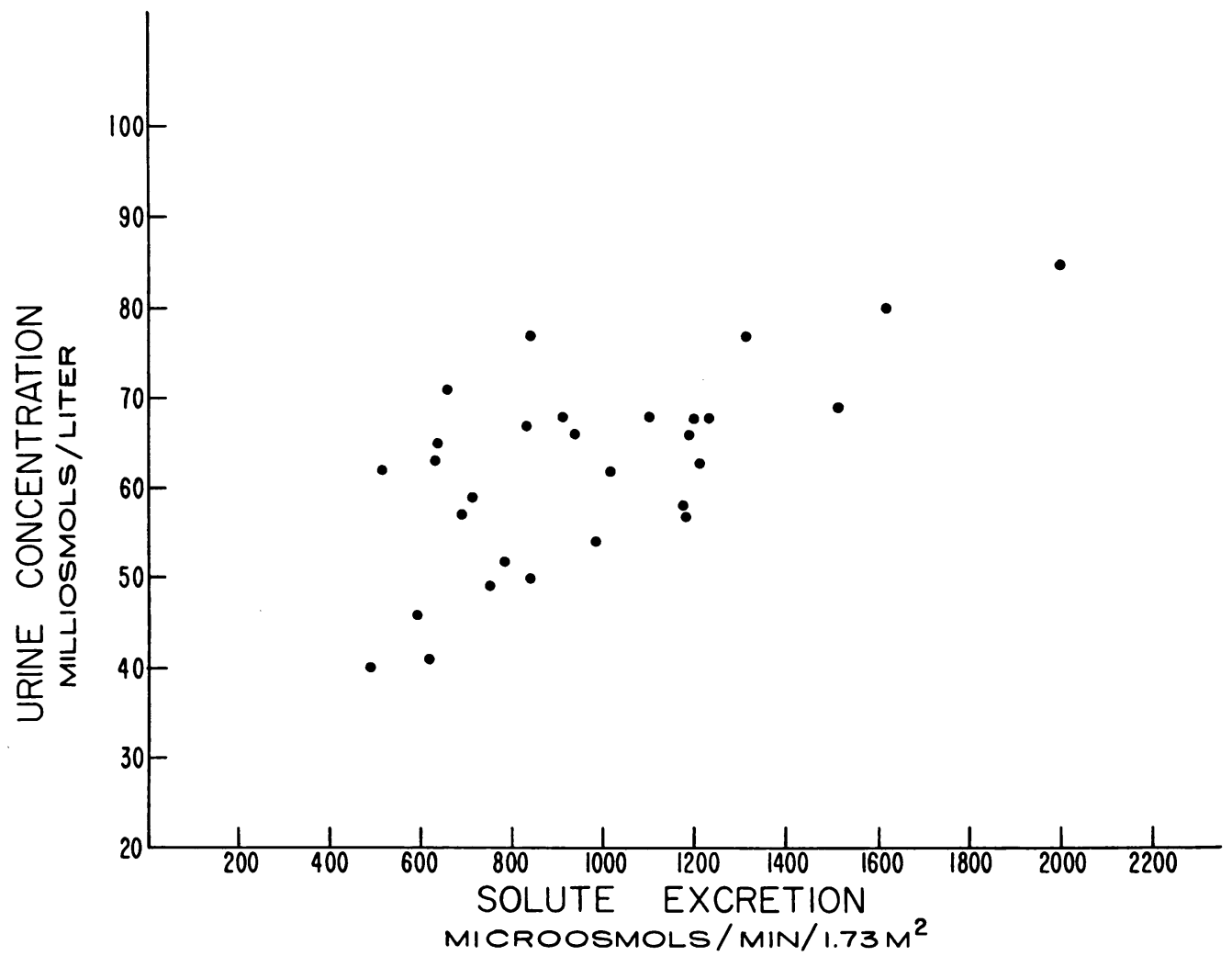

Fig. 2b. The Relationship Between the Minimal Urinary Osmolarity and the Rate of Solute Excretion at the Height of Sustained Water Diuresis

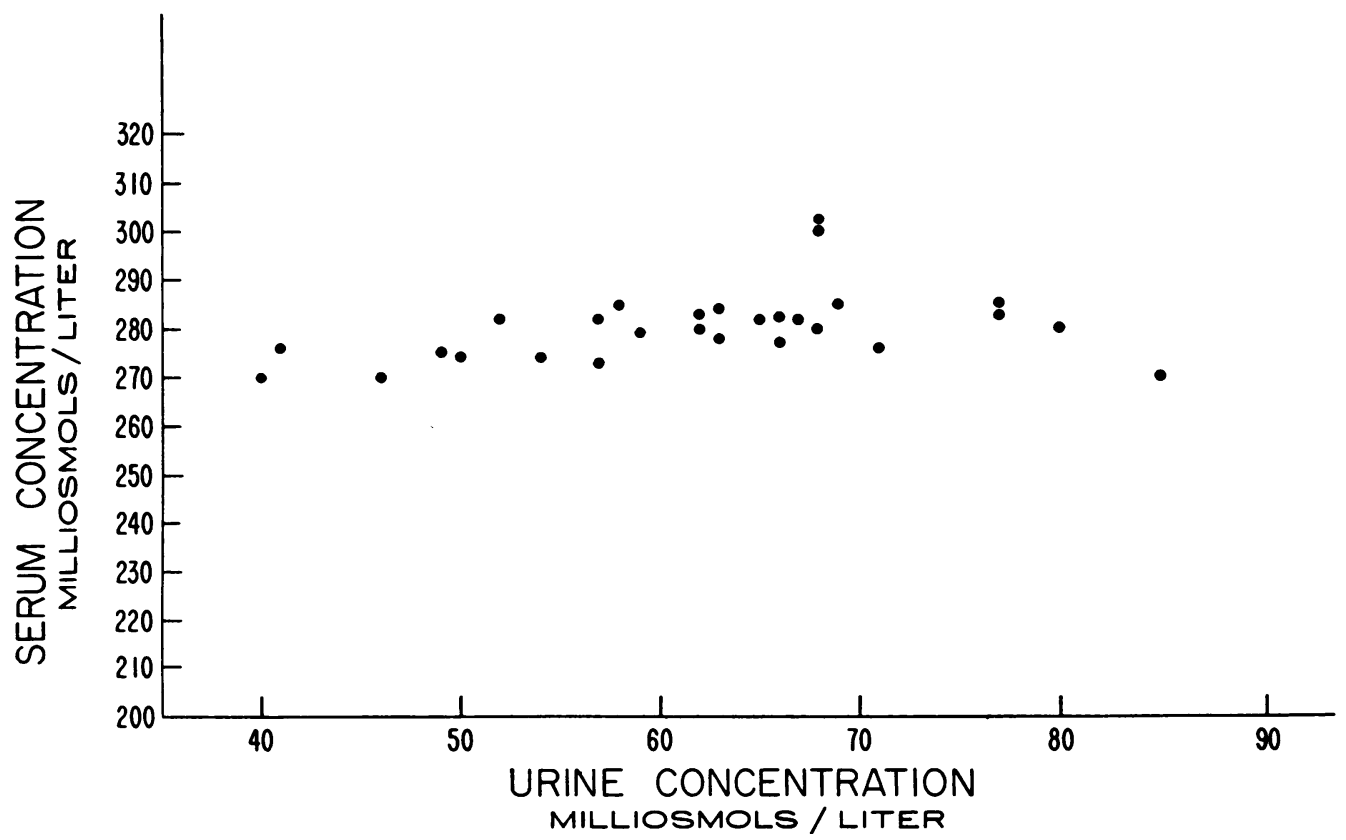

Fig. 3. Illustration of the Lack of Correlation Between the Minimal Urinary Osmolarity and the Osmolar Concentration of the Serum at the Height of the Diuresis 


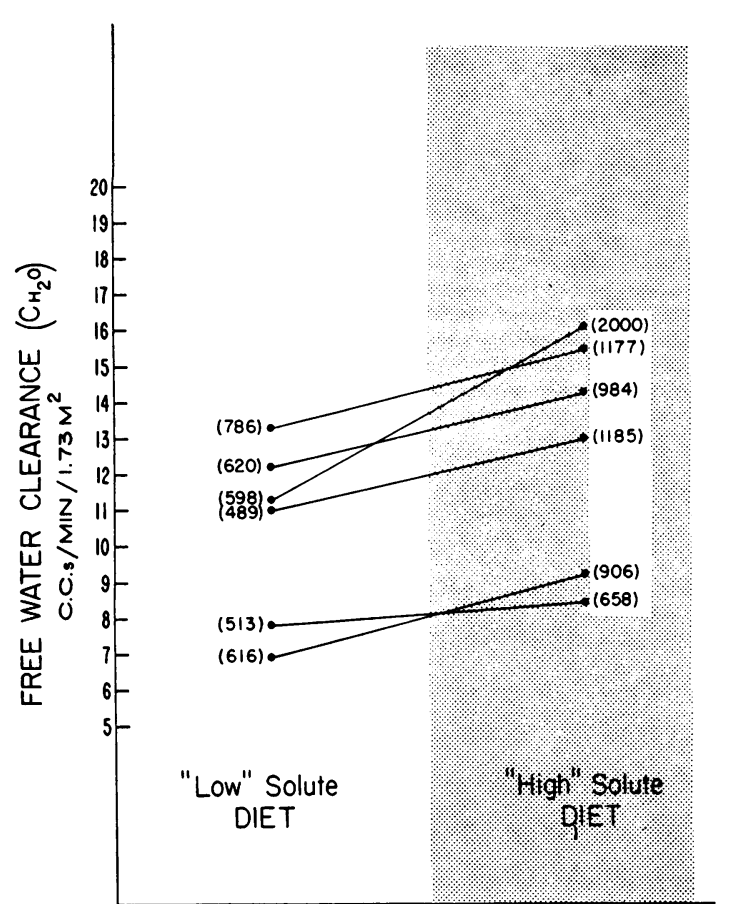

Fig. 4a. Illustration of the Effect of an Increase in the Rate of Solute Excretion upon the Free Water Clearance in Paired Dietary Experiments

The numbers in parentheses represent the rate of solute excretion in microosmols per minute. factor with solute load. The tests are given in Table IIa and reveal that creatinine clearance, in addition to any effect produced by virtue of its correlation with solute load, is also directly and independently correlated with maximal urinary flow.

b. Minimal urinary osmolarity (Table IIb) : In contrast to the direct correlation between total solute excretion and urinary solute concentration at the height of water diuresis, endogenous creatinine clearance inversely correlated with the minimal urinary osmolarity; i.e., the higher the creatinine clearance, the more dilute the urine.

This point is not established at a reasonable level of significance when the analysis is based on a single observation per subject but is justified if the 29 experiments are regarded as independent. This point has been referred to above.

c. Free water clearance $\left(\mathrm{C}_{\mathrm{H}_{2} \mathrm{O}}\right)$ : At the height of water diuresis, $\mathrm{C}_{\mathrm{H}_{2} \mathrm{O}}$ was directly correlated with the magnitude of the creatinine clearance (Table IIc). Inasmuch as $\mathrm{C}_{\mathrm{H}_{2} \mathrm{O}}$ is a derived, and not an observed value this statistical observation must be accepted with some reservation (6). However, if maximal urinary flow varies directly with cre-

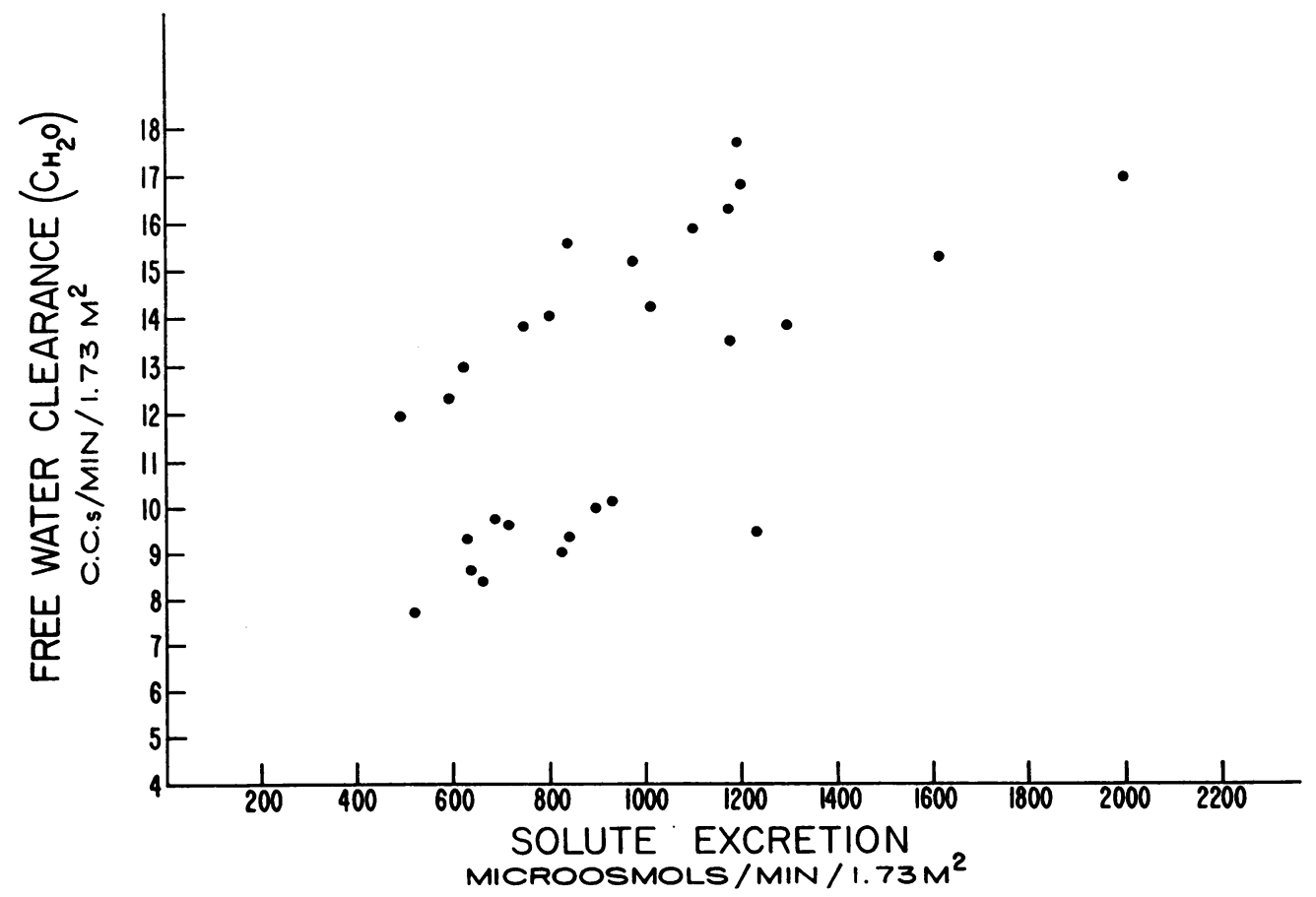

Fig. 4b. The Relationship Between the Free Water Clearance and the Rate of Solute Excretion at the Height of Sustained Water Diuresis 
atinine clearance while minimal urinary osmolarity varies inversely, then $\mathrm{C}_{\mathrm{H}_{2} \mathrm{O}}$, from its derivation, should correlate directly with glomerular filtration rate.

\section{DISCUSSION}

If one accepts the concepts that during maximal water diuresis all urinary water is derived from the glomerular filtrate and a minimal amount is reabsorbed in the distal segment of the nephron (7), then the magnitude of the diuresis is dependent on the amount of fluid delivered to this segment. The close correlation between maximal urinary flow and solute excretion (Figure 1) is consistent with this interpretation and substantiates the observations of Rosenbaum, Nelson, Strauss, Davis, and Rossmeisl (8) as well as those of others $(9,10)$. Although Welt and Nelson (11) concluded that the maintenance of maximal diuresis for long periods of time ( 4 to 6 hours) was not dependent on the rate of excretion of solute, in only one of their experiments was the maximum diuresis moderately well maintained and in this case the excretion of solute fell very little.

Rosenbaum and his associates (8) gave oral loads of urea and various sodium salts to their sitting subjects during water diuresis and concluded that sodium had a greater effect on urinary flow than the same osmolar quantity of urea. However, the expansion of extracellular volume which occurred with the salt loading, but not with urea, may have produced these differences, possibly by altering glomerular filtration rate or tubular reabsorption of salt and water (12). Statistical evaluation of the data in the present study did not show that tubular water was obligated differently by electrolytes than by urea (non-electrolytes) during water diuresis (Table III).

Observations by Wesson and Anslow (13), and Smith (7) during water diuresis and massive solute loading led these investigators to conclude that, at the height of water diuresis, the free water clearance $\left(\mathrm{C}_{\mathrm{H}_{2} \mathrm{O}}\right)$ was constant for any given animal or individual, and that under these circumstances the rise in urinary flow with increased excretion of solute represented simply the addition of isosmotic proximal tubular fluid to the urine. The close correlation between the rise in the minimal osmolarity and the rise in the excretion of solute (Figure 1) is consistent with this concept. However, in the present investigation, free water clear- ance was not a constant for any one individual but actually increased with increasing dietary intake and urinary excretion of solute (Figure 4). Similar changes in $\mathrm{C}_{\mathrm{H}_{2} \mathrm{O}}$ were noted by Rosenbaum and his associates (8) in experiments in which solute excretion was varied during water diuresis, by Welt, Young, Thorup, and Burnett (14) following the administration of a carbonic anhydrase inhibitor to subjects with maximal water diuresis, and in previous experiments from this laboratory (15). This rise in $\mathrm{C}_{\mathrm{H}_{2} \mathrm{O}}$ can be adequately explained by the reabsorption of additional solute in hypertonic solution, when further isosmotic fluid is delivered to the distal tubule.

The statistical observations in the present study strongly suggest that glomerular filtration rate (creatinine clearance) has an effect on maximal urinary flow, $\mathrm{C}_{\mathrm{H}_{2} \mathrm{O}}$ and minimal urinary osmolarity, independent of any effect on solute excretion. Ludemann, Raisz, and Wirz (16), studying water diuresis in dogs, observed lower minimal $\mathrm{U} / \mathrm{P}$ ratios for creatinine and higher maximal rates of urinary flow when creatinine clearance was increased by increasing the protein content of the diet. They thought that the increased excretion of urea could not explain these changes. Unfortunately they did not present data on the effect of the dietary change on total solute excretion. Rosenbaum and associates (8) minimized the role of glomerular filtration in the variations of maximal diuresis, because they demonstrated large changes in solute excretion and urinary flow with minimal changes in glomerular filtration. However, their data did not throw light upon the possible additional importance of changes in glomerular filtration rate.

The mechanisms by which variation in glomerular filtration per se could affect maximal urinary flow and $\mathrm{C}_{\mathrm{H}_{2} \mathrm{O}}$ are not clear. It is possible that a rise in filtration rate would increase the volume of isosmotic fluid delivered to the distal tubule, from which the additional solute but not the water could be reabsorbed. The net effect would be in increased urinary flow without a further increase in the excretion of solute. Shannon, in studies on dogs with diabetes insipidus, suggested another explanation (17). The increased rate of filtration, by increasing the velocity of flow along the proximal tubule, might prevent equilibrium between the actively reabsorbed solute and passively reab- 
sorbed water. The net effect would be the delivery of a greater quantity of water but no greater quantity of solute into the distal tubule and a consequent increase in urinary flow.

The statistical observation (Table IIb) that minimal urinary osmolarity varies inversely with the magnitude of glomerular filtration is inconsistent with the studies of Leaf, Kerr, Wrong, and Chatillon (18) who concluded from direct experiments in dogs that a decrease in filtration rate had no effect on minimal urinary osmolarity. However, it is supported by the findings of Berliner and Davidson (19), that decreasing the filtration rate in one kidney of a dog at the height of water diuresis causes an increase in the osmolar concentration of the urine above that produced by the contralateral kidney.

The relationships of glomerular filtration and the excretion of solute to the parameters of sustained water diuresis as noted in this study may be of fundamental importance in the pathogenesis of the impaired water excretion of such clinical states as cirrhosis of the liver, congestive heart failure, Addison's disease and panhypopituitarism, in all of which pathological lowering of glomerular filtration rate and/or solute excretion usually occur.

\section{SUMMARY}

1. Maximal sustained water diuresis was produced in 29 experiments in 17 normal semirecumbent subjects.

2. The effects of physiological variations in the dietary intake and urinary excretion of solutes and in glomerular filtration rate (endogenous creatinine clearance) upon maximal urinary flow, free water clearance $\left(\mathrm{C}_{\mathrm{H}_{2} \mathrm{O}}\right)$ and minimal urinary osmolarity were evaluated.

3. The magnitudes of the maximal urinary flow, $\mathrm{C}_{\mathrm{H}_{2} \mathrm{O}}$ and minimal urinary osmolarity were directly correlated with the rate of solute excretion.

4. Glomerular filtration rate (endogenous creatinine clearance) per se was directly correlated with maximal urinary flow and $\mathrm{C}_{\mathrm{H}_{2} \mathrm{O}}$ and inversely correlated with the minimal urinary osmolar concentration achieved during water diuresis.

\section{REFERENCES}

1. Wesson, L. G., Jr., Electrolyte excretion studies in the dog. Methods in Medical Research, 1952, 5, 175.
2. Hald, P. M., The flame photometer for the measurement of sodium and potassium in biological materials. J. Biol. Chem., 1947, 167, 499.

3. Elkinton, J. R., and Taffel, M., Prolonged water deprivation in the dog. J. Clin. Invest., 1942, 21, 787.

4. Hare, R. S., Endogenous. creatinine in serum and urine. Proc. Soc. Exper. Biol. \& Med., 1950, 74, 148.

5. Conway, E. J., Microdiffusion Analysis and Volumetric Error. 3rd rev. ed., London, C. Lockwood, 1950.

6. Snedecor, G. W., Statistical Methods. 4th ed., Ames, Iowa, Iowa State College Press, 1946.

7. Smith, H. W., Renal excretion of sodium and water. Federation Proc., 1952, 11, 701.

8. Rosenbaum, J. D., Nelson, W. P., III, Strauss, M. B., Davis, R. K., and Rossmeisl, E. C., Variation in the diuretic response to ingested water related to the renal excretion of solutes. J. Clin. Invest., 1953, 32, 394.

9. Relman, A. S., Goodyer, A. V. N., and Peterson, E. R., Effect of mannitol on salt excretion during water diuresis. J. Applied Physiol., 1949, 1, 601.

10. Smith, H. W., The Kidney: Structure and Function in Health and Disease. New York, Oxford University Press, 1951.

11. Welt, L. G., and Nelson, W. P., III, Excretion of water by normal subjects. J. Applied Physiol., 1952, 4, 709.

12. Wesson, L. G., Jr., Anslow, W. P., Jr., Raisz, L. G., Bolomey, A. A., and Ladd, M., Effect of sustained expansion of extracellular fluid volume upon filtration rate, renal plasma flow and electrolyte and water excretion in the dog. Am. J. Physiol., 1950, $162,677$.

13. Wesson, L. G., Jr., and Anslow, W. P., Jr., Effect of osmotic and mercurial diuresis on simultaneous water diuresis. Am. J. Physiol., 1952, 170, 255.

14. Welt, L. G., Young, D. T., Thorup, O. A., Jr., and Burnett, C. H., Renal tubular phenomena under the influence of a carbonic anhydrase inhibitor. Am. J. Med., 1954, 16, 612.

15. Kleeman, C. R., Rubini, M. E., Lamdin, E., and Epstein, F. H., Studies on alcohol diuresis. II. The evaluation of ethyl alcohol as an inhibitor of the neurohypophysis. J. Clin. Invest., 1955, 34, 448.

16. Ludemann, H., Raisz, L. G., and Wirz, H., Filtration rate and water diuresis in the dog. Am. J. Physiol., 1951, 166, 416.

17. Shannon, J. A., The control of the renal excretion of water. I. The effect of variations in the state of hydration on water excretion in dogs with diabetes insipidus. J. Exper. Med., 1942, 76, 371.

18. Leaf, A., Kerr, W. S., Jr., Wrong, O., and Chatillon, J. Y., Effect of graded compression of the renal artery on water and solute excretion. Am. J. Physiol., 1954, 179, 191.

19. Berliner, R., and Davidson, D., Personal communication. 